\title{
TAXONOMIES OF PHYSICS PROBLEMS IN PHYSICS EDUCATION
}

\author{
Monika Hanáková 1 , Daniel Kluvanec ${ }^{2}$
}

\begin{abstract}
Taxonomies of physics problems serve as useful tools to define and analyze the requirements of pupils and students in solving physics problems and tasks. The connection between taxonomies of educational objectives is important, and these were considered in selecting taxonomies of physics problems. Different approaches to classification are briefly described in this article, as well as the importance of a balance of physics problems in instruction, according to the selected taxonomy. Two taxonomies of physics problems were chosen according to our criteria and then analyzed and described in detail. A Strengths, Weaknesses, Opportunities, and Threats (SWOT) analysis was performed on the tools as well as an example of the use of the tools on a particular physics problem.
\end{abstract}

UDC Classification: 37.01/.02 DOI: http://dx.doi.org/10.12955/cbup.v4.808

Keywords: taxonomy, physics problem, physics task, physics education research.

\section{Introduction}

Physics problems, tasks, or questions in tests are one of the most widely used methods of checking and assessing knowledge of physics in education. Physics problems can be models of the physical world (Kluvanec, 2007), including situations from nature and techniques, and therefore, not only develop problem-solving skills, but also show the relationship between physics principles and life's situations. According to Hobden (1999), Maloney (1994) physics instructors generally believe that problemsolving leads to the understanding of physics and that it is a reliable way to demonstrate that understanding for purposes of evaluation (Gaigher, 2007). As McDermott (1991) and McMillan and Swadener (1991) mentioned, correct numerical ans wers do not necessarily imply that a corresponding level of conceptual understanding is reached, and this is often seen in the inability of students to explain the meaning of their own algebraic solutions of problems. A balance of physics problems that develop both low and high level skills should be carefully considered when planning physics instruction to improve this situation and for a systematic approach. Taxonomies of educational objectives with a high degree of generality are often chosen as the basis for evaluating the level of difficulty of physics problems.

\section{Different Approaches to Classification of Physics Problems}

Many authors from Slovakia, Czech Republic, and other countries deal with the classification of physics problems, tasks, or questions. Physics problems can be classified into various types depending on certain criteria (e.g., number of solutions and the form of presenting problems), as published by Kašpar et al. (1978). However, in our experience the classification of physics problems according to their difficulty for a particular group of students is often more important than the particular type of problem, in terms of physics instruction.

In textbooks, the more difficult physics problems are simply distinguished by a special sign. However, as Redish, Scherr, and Tuminaro (2006) mentioned, problems that appear to be simple to physicists or physics teachers and instructors are not often seen that way by students. Therefore, more detailed approaches have been suggested.

The first approach in the classification of physics problems according to their difficulty is characterized as analyzing students' solutions and success in solving physics problems. This is usually quantified by either a mark or number of gathered points, as Kluvanec (1997) mentioned, or the number of students who can solve the physics problems, as suggested by Volf (2004). An alternative approach of evaluating the different level of questions and corresponding answers in a range of educational settings (Buick, 2010) was provided by Biggs and Collis (1982) as Biggs SOLO

\footnotetext{
${ }^{1}$ Monika Hanáková, Faculty of Natural Sciences, Constantine the Philosopher University in Nitra, Slovakia monika.hanakova@ukf.sk

${ }^{2}$ Daniel Kluvanec, Faculty of Natural Sciences, Constantine the Philosopher University in Nitra, Slovakia, dkluvanec@ukf.sk
} 
Taxonomy, where SOLO means Structure of Observed Learning Outcomes. The main consideration in this taxonomy of five levels is the number of connections, namely, the relationships within or beyond the subject area, and the ability of students to demonstrate these in written solutions.

On one hand, success and the quality of students' solutions can be an important indicator of the difficulty of physics problems. On the other hand, as Kluvanec (1997) mentioned, the information about the group of students that it provides may have more relevance than that of the physics problem itself.

Teachers, however, need a tool to identify the level of probable difficulty of chosen physics problems before using them, without the need to analyze the solutions of students. Taxonomies of educational objectives are such tools and these have a high degree of generality, i.e., they are not subject specific. Krathwohl (2002) characterized them as a framework for classifying statements of the expected or intended results of student instruction. In general, they are a classification system of levels, where each level is a pre-requisite for the next one. Bloom Taxonomy, including its modifications and variations, is one that is widely used in course development, where a range of physics questions, as well as problems, are considered and categorized by the level of knowledge and understanding that is required for a successful answer (Buick, 2010). Applications of this approach have resulted in creating further taxonomies of physics problems or models of classifying physics problems.

\section{Selection of Taxonomies and Models of Physics Problems}

There is a variety of taxonomies available and those with analyses of advantages and disadvantages with an example, could be useful for teachers. Classification of educational tasks suggested by Tollingerová et. al. (1986), in a close coherence with Bloom Taxonomy, has been applied in many fields to date. It consists of five main types and 27 subcategories considering operational structure. A few examples of its application in physics problems was presented by Žák (2011).

The main objective of this article is to present and implement method in selecting the most appropriate taxonomy that was primarily created for evaluating physics problems in educational settings. To achieve this, the Strengths, Weaknesses, Opportunities, and Threats (SWOT) analysis was performed. As it was not possible to analyze possible taxonomies, we chose two that fulfilled criteria we had defined as the most important for educational settings, namely, $\mathrm{C} 1$ : taxonomies of educational objectives should be included in the taxonomies of physics problems, C2: verification in physics education research, C3: applicability in primary and secondary schools, and C4: no necessity to analyze the success of students' solutions in considering the level of physics problems according to this taxonomy.

\section{Taxonomy of Introductory Physics Problems (TIPP)}

The Taxonomy of Introductory Physics Problems (TIPP) is a classification of physics problems in the context of introductory physics courses. It involves a database containing text-based and researchbased physics problems that explain their relationship to cognitive processes and knowledge. Teodorescu, Bennhold, Feldman, and Medsker (2013) described this taxonomy using examples of classification and discussed its validity and reliability (Figure 1).

As the basis of the TIPP, the New Taxonomy of Educational Objectives (NTEO), by Marzano and Kendal (2007), was chosen. The NTEO satisfied all criteria defined by the authors of TIPP. First, it addressed problem-solving in the list of cognitive processes. Second, it involved both knowledge domains and cognitive processes that have been identified by physics education research (PER) as relevant for physics problem solving. Third, it distinguished between the cognitive processes and the knowledge involved in the problem solving. It also assumed that students will have no previous exposure to the particular (or similar) problem and have only basic relevant knowledge. There is the belief that a student who solves the same problem many times engages in different cognitive processes to that of a student who sees it for the first time. The application of the NTEO consists of three systems of thinking (cognitive, metacognitive, and self-system divided into six levels) and three knowledge domains (information, mental, and psychomotor procedures). The TIPP is focused on a cognitive system of thinking and on information and mental procedures, and is designed for pen-andpaper tasks. Characteristics of domains, as well as subcategories of cognitive system (both for information and mental procedures), are shown in Figure 1 and a SWOT analysis in Table 1. 
Figure 1: A scheme of the Taxonomy of Introductory Physics Problem (TIPP)

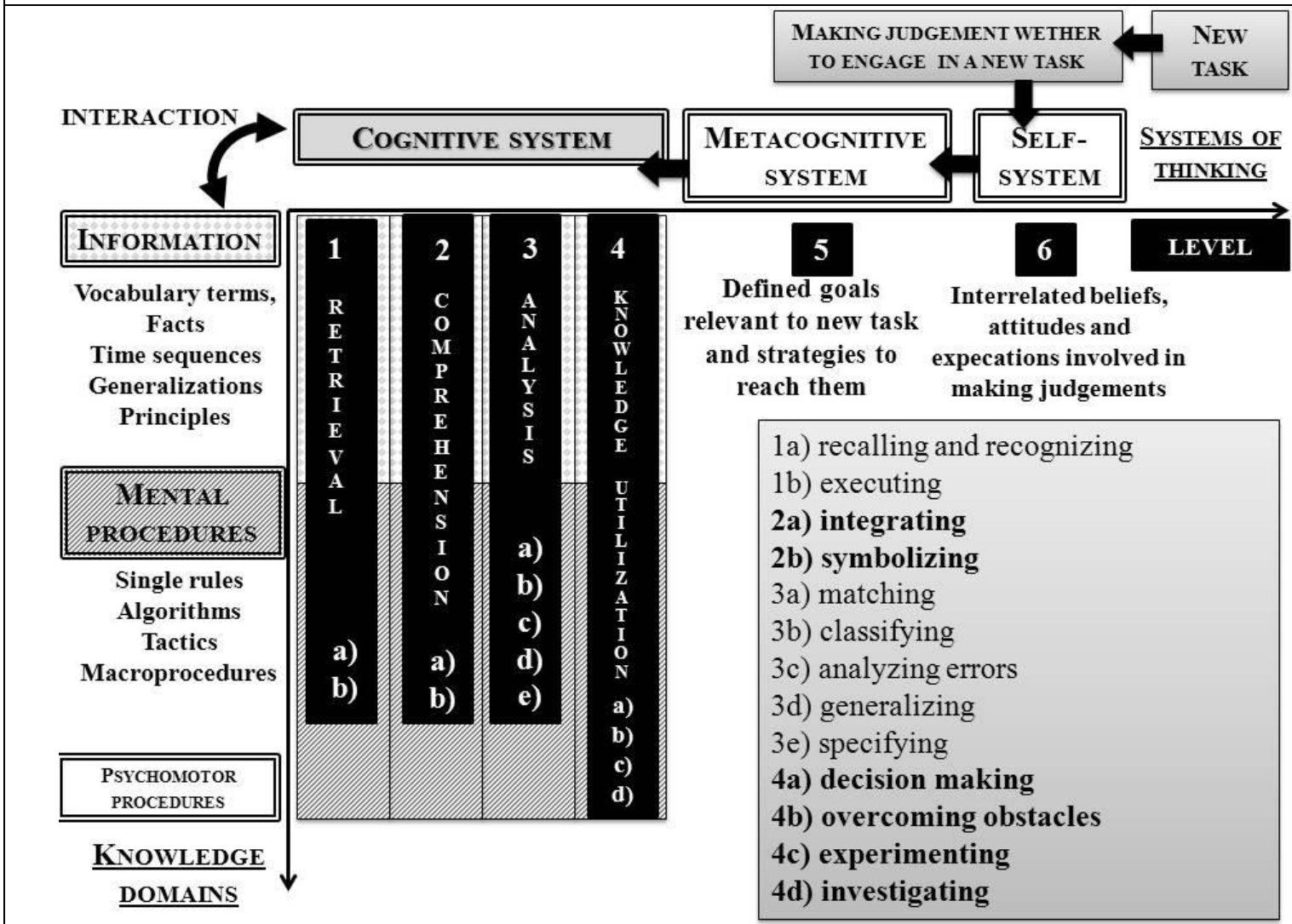

Source: Elaborated according to Teodorescu et al. (2013)

Table 1: Strengths, Weaknesses, Opportunities, and Threats (SWOT) analysis of Taxonomy of Introductory Physics Problems (TIPP)

\begin{tabular}{|l|l|}
\hline \multicolumn{1}{|c|}{ Strengths } & \multicolumn{1}{|c|}{ Weaknesses } \\
\hline $\begin{array}{l}\text { It satisfies our criteria of } \\
\text { C1: NTEO* is used, one of the latest modifications } \\
\text { of Bloom Taxonomy, }\end{array}$ & $\begin{array}{l}\text { For physics tasks, where the method } \\
\text { of solution is known by solver, other } \\
\text { factors could be considered }\end{array}$ \\
$\begin{array}{l}\text { C2: physics problems from PER**, } \\
\text { after consideration, and } \\
\text { C4: well as defined method of classification with } \\
\text { examples for every type }\end{array}$ & \\
\hline $\begin{array}{l}\text { Tool with measured validity and reliability } \\
\text { Opportunities }\end{array}$ & Threats \\
\hline $\begin{array}{l}\text { Similar approaches (the source taxonomy NTEO) could be } \\
\text { used for primary and secondary schools as pupils and } \\
\text { students, as we consider that pupils on lower level have } \\
\text { only basic relevant knowledge compared to the procedures } \\
\text { and knowledge used at higher levels (as was the assumption } \\
\text { for university physics introductory courses) }\end{array}$ & $\begin{array}{l}\text { Using this taxonomy by teachers, } \\
\text { could be more complicated as the } \\
\text { categories defined in NTEO are not } \\
\text { as widely known as Bloom } \\
\text { Taxonomy and the characteristics of } \\
\text { subcategories should be carefully } \\
\text { studied }\end{array}$ \\
\hline Notes: *NTEO - New Taxonomy of Educational Objectives; $* *$ PER - Physics Education Research \\
\hline
\end{tabular}

Source: Author 


\section{Model of Bloom Taxonomy, Mathematical Models, Scope of Themes and Convergence (BMTK)}

This BMTK model was created because of the need for an objective but simple way to evaluate physics problems according to cognitive operations and performance of students for problem solving. It is based on the original Bloom Taxonomy, represented by the letter "B". Three elements of Creativity and Performance Features (CPF) are then considered, namely, "M" for mathematical models, "T" for scope of themes, and " $\mathrm{K}$ " for convergence or divergence of physics problem. These components are based on the previously published characteristics of solving physics problems by Kluvanec (1997). They were adopted for simplicity of a model and the assumption that an objective identification was possible. For example, when subcategories are identified in the physics task or problem, the highest attainable value of index is written, instead of the letters BMTK, as 2 x10 (Figure 2).

Figure 2: Model of Bloom Taxonomy, Mathematical Models, Scope of Themes and Convergence (BMTK)

Cognitive operations

\begin{tabular}{|c|c|c|}
\hline \multirow{3}{*}{$\begin{array}{l}\text { B (Bloom) } \\
1 \text { - knowledge } \\
2 \text { - comprehension } \\
3 \text { - application } \\
4 \text { - analysis } \\
5 \text { - synthesis } \\
6 \text { - evaluation }\end{array}$} & $\begin{array}{c}\text { M - mathematical } \\
\text { models }\end{array}$ & $\begin{array}{l}0 \text { - from the previous grades } \\
1 \text { - from actual grade } \\
2 \text { - above standard of actual grade } \\
X \text { - qualitative tasks }\end{array}$ \\
\hline & $T$ - scope of themes & $\begin{array}{l}0 \text { - task corresponding to actual topic } \\
\text { theme on physics instruction } \\
1 \text { - themes from one chapter } \\
2 \text { - themes from more chapters } \\
3 \text { - different parts of physics course }\end{array}$ \\
\hline & $\begin{array}{c}\mathrm{K} \text { - convergence/ } \\
\text { divergence }\end{array}$ & $\begin{array}{l}0 \text { - convergent tasks } \\
1 \text { - divergent tasks }\end{array}$ \\
\hline
\end{tabular}

Source: Rakovská and Dežerický (2002)

\section{Elements of Creativity and Performance Features (CPF)}

The indexes, either numbers or the letter "X" (Figure 2), define the subcategories of elements of CPF. Indexes provide the teacher with important information about the chosen physics problem without the need to solve or analyze it. The SWOT analysis of this model is shown in Table 2.

Table 2: Strengths, Weaknesses, Opportunities, and Threats (SWOT) analysis of model of Bloom Taxonomy, Mathematical Models, Scope of Themes and Convergence (BMTK)

\begin{tabular}{|c|c|}
\hline Strengths & Weaknesses \\
\hline $\begin{array}{l}\text { It satisfies our criteria of } \\
\text { C1: Bloom Taxonomy included, } \\
\text { C2: research at grammar school, } \\
\text { C3: useable, } \\
\text { C4: possible to classify physics problems before using } \\
\text { them in instruction as far as the system of active verbs is } \\
\text { described and analysis of possible solutions can be done }\end{array}$ & \multirow[t]{3}{*}{$\begin{array}{l}\text { Identification of the value of indexes of } \mathrm{M}, \mathrm{T} \\
\text { elements can vary because of slight differences of } \\
\text { the order and understanding of mathematical } \\
\text { models and themes (the problem can be solved by } \\
\text { defining model of curriculum used) }\end{array}$} \\
\hline $\begin{array}{l}\text { Observed agreement between this model and the other way of } \\
\text { assessment of students' performance at grammar school }\end{array}$ & \\
\hline Examples of this method analyzed & \\
\hline Opportunities & Threats \\
\hline It can be used as a tool for reformulating physics problems & $\begin{array}{l}\text { While using this model by teachers to classify } \\
\text { group of physics problems their indexes can vary } \\
\text { according to their experience }\end{array}$ \\
\hline $\begin{array}{l}\text { Two-dimensional revised Bloom Taxonomy could be chosen } \\
\text { for deeper analysis }\end{array}$ & Level of creativity is not defined here \\
\hline
\end{tabular}




\section{Example of Classification According to TIPP and model BMTK}

An example problem from Teodorescu et al. (2013) is:

A cart of mass $m$ moves with a speed $v$ on a frictionless air track and collides with an identical cart that is stationary. If the two carts stick together after the collision, what is the final kinetic energy of the system? (p. 6)

The method of classifying this example in TIPP involves identifying the highest complexity in the cognitive process necessary to solve the problem. Categories for both information and mental procedures, defined in Teodorescu et al. (2013) and presented in Figure 1, are identified for every classified physics problem. This example is classified by "I" as 2 and "MP" as 1 , where "I" stands for information and "MP" for mental procedures. In a more detailed approach subcategories and their indexes are analyzed. Only those subcategories identified in a physics problem are considered in classification of it, sometimes omitting few subcategories if these were not requested in a particular physics problem. More detailed classification of example problem is provided by following subcategories (see Figure 1) for information (I): 1a) recalling the concepts of mass, velocity, momentum, and kinetic energy; 1b) integrate facts where key elements need to be taken into account, and $2 \mathrm{~b}$ ) representing information where the highest is 2 for comprehension. Regarding mental procedures (MP), the student needs to execute (1b), draw an appropriate picture, write conservation of momentum law, solve for velocity, and calculate the kinetic energy (Teodorescu et al., 2013).

As an example, the BMTK model could illustrate a problem in secondary education as $2{ }_{110}$. In brief, for the question "what is the final kinetic energy?", the model components could be B = 2 for comprehension, with the active verb "is", which in this case means "to execute"; $M=1$ for an equation of mathematical models from primary school or the actual grade; $\mathrm{T}=1$ to 2 for a theme from one or two chapters (depending on curriculum); and $\mathrm{K}=0$ for a convergent problem.

\section{Discussion}

The main distinctive features of TIPP and BMTK taxonomies of physics problems were compared by SWOT analysis (Table 1, Table 2). Both taxonomies fulfil our defined criteria. Wider utilization of them in educational settings can be realized after providing a brief introduction for teachers. Vital information about physics problems, which are planned to be solved by students, needs to be understood by users of selected taxonomy. Classification of physics problems slightly depends on the experience of teachers with classifying physics problems according to a certain taxonomy.

We also identified the main differences between TIPP and BMTK according to SWOT analyses. First, they differ in a selected modification of Bloom taxonomy (Bloom Taxonomy for BMTK and the NTEO for TIPP). Second, information provided to teachers or solvers of classified physics problems differs as well. Creative and Performance Features are expressed only in BMTK. Knowledge and mental procedures are clearly expressed and distinguished in TIPP.

The choice of the best taxonomy of physics problems was the main objective of this article. We consider TIPP to be the best taxonomy for educational purpose. It enables teachers to plan whether knowledge or certain algorithms are needed to be revised, practiced or assessed. However, an extra information about the difficulty of requested mathematical operations would be beneficial, as it could be an obstacle in solving physics problems for less skilled students.

\section{Conclusion}

In this article, we endeavored to show the importance and usefulness of taxonomies of physics problems in physics education. Taxonomies are useful tools for planning physics instruction and in assessing students. Selecting the most appropriate one can be achieved by using criteria for a particular purpose. The characteristics of selected taxonomies, the BMTK model and the TIPP, were compared using SWOT analyses. For teachers and instructors, searching for a simple tool of classifying primary and high school physics problems, where one-dimensional Bloom taxonomy is sufficient for defining physics problems, the BMTK model, is suitable. Moreover, it can provide information about the required performance, although this depends on the particular curriculum, as values of indexes vary with the chosen grade. The taxonomy, known as TIPP, is primarily used for university introductory 
courses and, in our opinion, is applicable at high schools. Its advantage is the clear distinction between the attained levels in cognitive processes and knowledge domains that can be identified using this method. The selected and mentioned taxonomies are not the only tools that are appropriate for physics education, but approaches shown in this study for analyzing such tools can be useful for choosing the most appropriate one for a particular purpose.

\section{References}

Biggs, J. B., \& Collis, K. F. (1982). Evaluating the quality of learning - the SOLO Taxonomy. New York: Academic Press.

Buick, J. M. (2010). Physics Assessment and the Development of a Taxonomy. European J of Physics, 2 (1), 12-27. Retrieved from http://www.acarindex.com/dosyalar/makale/acarindex-1423880556.pdf

Gaigher, E. (2007). Exploring the Development of Conceptual Understanding through Structured Problem-solving in Physics. International Journal of Science Education. http://dx.doi.org/10.1080/09500690600930972

Hobden, P. A. (1999). The context of problem tasks in schol physical science [Doctoral dissertation]. Durban, South Africa: University of Natal.

Kašpar, E., Hniličková-Fenclová, J., Lepil, O., Skalický, V., Vachek, J., Vlach, B. (1978). Didaktika fyziky. 1. vyd. Praha: Státní pedagogické nakladatelství [Didactics of Physics. 1st ed. Prague: State Pedagogical Publishing].

Kluvanec, D. (1997). Kreatívno-výkonové charakteristiky fyzikálnych úloh. [Creative-Performance Features of Physical Tasks.] DIDFYZ'96: Natural Sciences Education for the 21st Century. Nitra: UKF Nitra, JSMF, 75-81. ISBN 80-8050-087-8

Kluvanec, D. (2007). Fyzikálna úloha - cielený model reality. [Physical task - targeted model of reality.] CoPhys International Physics Workshop 2006, Nitra: UKF. 189-201. ISBN 978-80-8094-084-3 Retrieved from http://www.kf.fpv.ukf.sk/Biblioteka/CoPhys/CoPhys_2006.Master.pdf

Krathwohl, D. R. (2002, Autumn). A Revision of Bloom's Taxonomy: An Overview. Theory into practice. 41(4). Retrieved from http://www.unco.edu/cetl/sir/stating_outcome/documents/Krathwohl.pdf

McDermott, L. C. (1991). Millikan lecture 1990: What we teach and what is learned - closing the gap. American Journal of Physics, 59, 301-315.

McMillan, C., \& Swadener, M. (1991). Novice use of qualitative versus quantitative problem solving in electrostatics. Journal of Research in Science Teaching, 28, 661-670.

Maloney, D. P. (1994). Research on problem solving: Physics. Handbook of research in science teaching and learning. New York: Macmillan, 327-354.

Marzano R. J., \& Kendall J. S. (2007). The New Taxonomy of Educational Objectives. Thousand Oaks, CA: Corwin Press.

Rakovská, R., \& Dežerický, L. (2002). K hodnoteniu úrovne náročnosti fyzikálnej úlohy. Fyzika - matematika - informatika [To evaluate the level of difficulty of physical tasks. Physics - Mathematics - Informatics], 11 (6), $344-352$.

Redish, E. F., Scherr, R. E., \& Tuminaro, J. (2006). Reverse-engineering a solution of a "simple" physics problem: Why learning physics it is harder than it looks? Phys. Teach. 44, 293.

Teodorescu, R. E., Bennhold, C., Feldman, G., \& Medsker, L. (2013). New approach to analyzing physics problems: A Taxonomy of Introductory Physics Problems. Physical review special topics - Physics education research, http://dx.doi.org/10.1103/PhysRevSTPER.9.010103

Tollingerová, D. Holoušová D., Horák, F. Chráska, M., Kantorková, H., Komenda, S., Sýkora, J. (1986). K teorii učebních činností. 1. vyd. Praha: SPN. [About the Theory of educational activities. 1st ed. Prague: SPN] 197-198

Volf, I. (2004). Jsou fyzikální úlohy pro žáky obtížné? Matematika-fyzika-informatika [Are Physical Tasks difficult for pupils? Mathematics - Physics - Informatics], 14 (3), 157 - 162.

Žák, V. (2011). Nezapomínejme na různe typy fyzikálních úloh! Matematika-fyzika-informatika [Do not forget the many forms of physical problems! Mathematics - Physics - Informatics], 20 (10), 604-613. 